\title{
Building and Testing a Spin Coater for the Deposition of Thin Films on DSSCs
}

\author{
Edwalder Silva Teixeira ${ }^{a *}$ (1), Raphael Coelho Cavalcantib, Vanja Fontenele Nunes ${ }^{a}$,

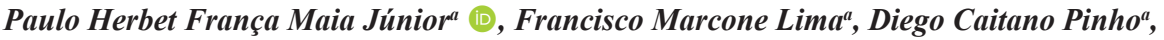

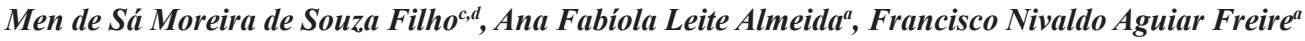 \\ ${ }^{a}$ Universidade Federal do Ceará, Laboratório de Filmes Finos e Energias Renováveis (LAFFER), \\ Campus do Pici, 60455-900, Fortaleza, CE, Brasil \\ ${ }^{b}$ Universidade de Fortaleza, Fortaleza, CE, Brasil \\ 'Instituto Federal do Ceará, Fortaleza, CE, Brasil \\ ${ }^{d}$ Embrapa Agroindústria Tropical, Fortaleza, CE, Brasil.
}

Received: May 16, 2020; Revised: October 20, 2020; Accepted: November 02, 2020

\begin{abstract}
A low cost spin coater was constructed in this work for the deposition of thin films of titanium dioxide $\left(\mathrm{TiO}_{2}\right)$ on conductive substrate of FTO (fluoride doped tin oxide) with application on dye sensitized solar cells. The results showed a $95 \%$ precision between the speed values obtained by the software of $\mathrm{C \#}$ sharp language and the spin values observed directly on the device. The $\mathrm{TiO}_{2}$ films deposited through the spin coater with different angular speeds were characterized by UV-Vis optical spectrum, scanning electron microscopy (SEM), atomic force microscopy (AFM) and electrical measurements on an active area of $0.25 \mathrm{~cm}^{2}$. The DSSCs assembled with the $\mathrm{TiO}_{2}$ films of double layer deposited by the spin coater had an efficiency value of $12.74 \%$, while the cell with a single layer presented $4.05 \%$ efficiency. Therefore, it is concluded that the spin coater assembled in this study at low costs successfully can produce $\mathrm{TiO}_{2}$ electrodes for DSSCs.
\end{abstract}

Keywords: Spin coater, spin coating, DSSCs, thin film, TiO,

\section{Introduction}

The advances on nanotechnology and nanoscience allowed the development of functional and nanoscale electronic devices, manufactured with thin films. The techniques for depositing these films are many, spray pyrolysis ${ }^{1}$, dip coating $^{2}$, doctor blade ${ }^{3}$ and, highlighting, the spin coating process ${ }^{4}$. These methods share in common the potential for application in many industrial sectors and the technological and economic benefits.

Spin coating is a technique that drops a solution on a substrate during a rotation movement, where the parameters are: speed, momentum, rotation time and solution viscosity. During the deposition, the more volatile components of the solution evaporate by the contact with the humidity or the surrounding air, improving the hydrolysis and condensation ${ }^{5,6}$.

Spin coaters can form micrometers $(\mu \mathrm{m})$ and nanometer (nm) thin films, with application on devices such as, transitors ${ }^{7,8}$, gas sensors $^{9,10}$, supercapacitors ${ }^{11,12}$, light emitting diodes ${ }^{13,14}$. Addtionally, it also deposits titanium dioxide $\left(\mathrm{TiO}_{2}\right)$ thin films on conductive glass. These films can be used on dye sensitized solar cells (DSSCs) ${ }^{15-17}$.

Titanium dioxide is a semiconductor with large band gap, a common material used for DSSCs, and has a function of trapping electrons from the oxidation of the dye by the absorption of sunlight and transport these electrons through the conduction band of the film to the conductive glass

*e-mail: edwalderteixeira@hotmail.com and, then, through the external circuit ${ }^{15-19}$. With the great transmittance in the visible range $\mathrm{e}^{15-19}, \mathrm{TiO}_{2}$ is one of the most used semiconductor in the photovoltaic solar energy sector.

Spin coating is a simple technique of easy application, making homogeneous films of reduced thickness, at low temperatures, low costs and with flexible polymeric substrates ${ }^{6,20-23}$. However, the industrial spin coaters can add high acquisition values due to its components such as acceleration control, rotation, speed and time, all programmed by electronic circuits.

To tackle the problem of high instrument cost, the present work has endeavored to develop and build low cost spin coater equipment for deposition of thin $\mathrm{TiO}_{2}$ films apply on DSSCs electrodes. The development of $\mathrm{TiO}_{2}$ based electrodes using the spin coating technique can assemble DSSCs that present a good option to the silicon photovoltaic solar cells. There are studies which show $\mathrm{TiO}_{2}$ electrodes on DSSCs with efficiencies of $5.62 \% 0^{17}, 6.35 \%{ }^{18}$, e $6.4 \%{ }^{19}$.

In this context, this work presented the development and test of a low cost, alternative spin coater to deposit $\mathrm{TiO}_{2}$ thin films on the conductive substrate of FTO for application on DSSCs. To operate the device, a C\#sharp language was used to control parameters such as angular speed $(\omega)$ and thickness efficiently and through a serial portal of the computer, eliminating the use of the industrial electronic components. Another highlight is the making of a substrate holder that allowed to fixate the substrate, without tapes or vacuum pumps. 
The aim of this study is to build a simple device at low costs to produce $\mathrm{TiO}_{2}$ electrodes and apply those on DSSCs. For analysis and comparison, it was built with two DSSC, with different photoanodes. The first one, single $\mathrm{TiO}_{2}$ layer, was made with the $\mathrm{TiO}_{2}$ deposited by screen print by Solaronix. The second was made by adding a $\mathrm{TiO}_{2}$ layer deposited by the spin coater on the $\mathrm{TiO}_{2}$ deposited by the manufacturer (commercial), resulting in a double layer photoanode. The DSSCs were characterized electrically by the plots of current density (Jsc) versus voltage (V), to calculate the cell efficiency.

\section{Spin Coating Process}

The spin coating process is a procedure to deposit uniform films on substrates. The process (Figure 1) is made by distinct stages: 1) The solution is dropped on the substrate that, at the beginning can be at rest or rotating. After deposition, the substrate is accelerated so through the centrifugal force, the solution can be dispersed on the substrate, radially throughout the edges ${ }^{5,24-30} .2$ ) The speed is kept stable, with the balance between the centrifugal forces and the viscosity forces to create a homogeneous film. 3) The substrate is kept at constant speed to evaporate the remaining solvent ${ }^{5,24-30}$. Besides keeping a balance between the acting forces, the constant speed helps the evaporation rates, an important parameter to obtain a homogeneous film 5 .

Other important parameters are: angular speed $(\omega)$, angular acceleration of rotation $(\alpha)$, fluid viscosity $(\Pi)$, rotation time $(t)$ and solution concentration $(C)^{5}$.

The parameters previously mentioned are used for modelling the spin coating process, which relates analytical models with sophisticated mathematical expressions Equations 1 to $9^{24,26-29}$ and assume:

1. No gravity effect;

2. Newton incompressible fluid;

3. Radially symmetric flux;

4. Constant density and viscosity;

5. Use of the momentum continuous equation with cylindrical polar coordinates.

Based on the previously cited assumptions and, also, taking that during the formation of the film, the angular speed is kept constant, balancing the centrifugal and viscous forces, Equation $1^{24,26-29}$ is described as following.
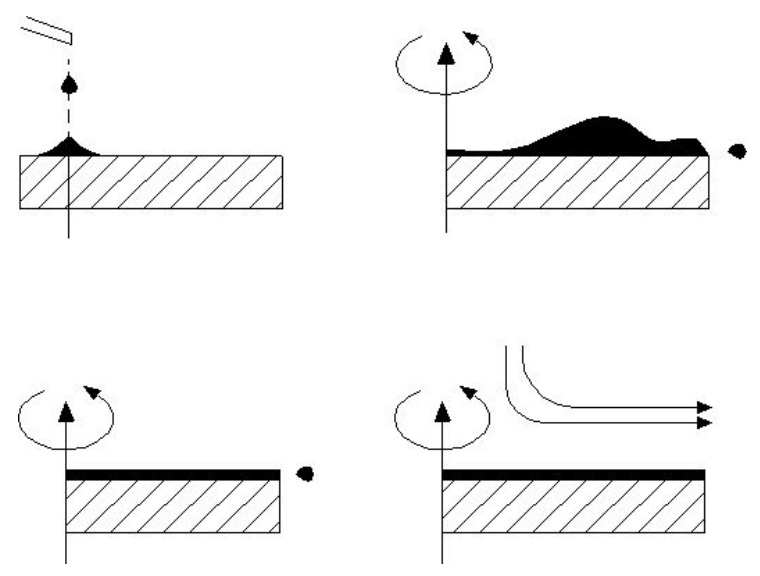

Figure 1. Stages of the spin coating deposition process ${ }^{24}$. $-\eta\left(\frac{d^{2} v}{d z^{2}}\right)=\rho \omega^{2} r$

$\eta=$ absolute viscosity;

$\rho=$ fluid density;

$v=$ speed in the radial direction $(\mathrm{r})$;

$\omega=$ Angular rotation speed.

When analysing the borders conditions of the substrate surface $(\mathrm{z}=0)$, where $v=0, \partial v / \partial z=0$ and at the surface of the deposited liquid $(\mathrm{z}=\mathrm{h})$ with the presence of the viscous force, adding the integration of Equation 1, with the declared limits, the linear speed at the surface is as following Equation 2:

$v=\frac{1}{\eta}\left(-\frac{1}{2} \rho \omega^{2} r z^{2}+\rho \omega^{2} r h z\right)$

The radial flux, $q$, per circumference length unit is:

$q=\int_{0}^{h} v(z) d z=\frac{\rho \omega^{2} r z h^{3}}{3 \eta}$

The continuity Equation 4 is used to find the differential of h.

$\frac{\partial h}{\partial t}=-\frac{1}{r}\left(\frac{\partial(r q)}{\partial r}\right)=-K\left(\frac{1}{r}\right) \frac{\partial}{\partial r}\left(r^{2} h^{3}\right)$

where $K=\frac{\rho \omega^{2}}{3 \eta}$

The result of Equation 4 takes into consideration the solution which relates $\mathrm{h}$ with time. Then:

$$
\frac{\partial h}{\partial t}=-2 K h^{3}+3 K r h^{2}\left(\frac{\partial h}{\partial r}\right)
$$

This way, having a uniform film at the beginning, $h$ is independent of $\mathrm{r}$ and $\frac{\partial h}{\partial r}=0$ so,

$\frac{\partial h}{\partial t}=-2 K h^{3}$

And, by separating variables, the film thickness reduction rate is:

$\frac{\partial h}{h^{3}}=-2 K \partial t$

Integrating both sides of Equation 7, with the limits $\mathrm{t}=0$, $\mathrm{h}=\mathrm{h}_{0}$ and $\mathrm{h}=\mathrm{h}_{\mathrm{t}}$ at $\mathrm{t}$ :

$$
h=\frac{h_{0}}{\sqrt{1+4 K h_{0}^{2} t}}=\frac{h_{0}}{\sqrt{1+\frac{4 h_{0}^{2} \rho \omega^{2} t}{3 \eta}}}
$$

where $h_{0}$ represents the initial thickness of the film at time $\mathrm{t}$ equals zero. However, it is not applicable because at the beginning the solution is unstable.

Another important observation is that, for long periods of time, high quantities of solution deposited on the substrate do not affect the final film thickness. Additionally, $h$ is proportional to the inverse of the square root of time Equation 9 and there is reduction of the thickness with increasing the angular speed ${ }^{24,26-29}$.

$h=\frac{\sqrt{3 \eta}}{2 \omega} \frac{1}{\sqrt{t}}$

Equation 9 follows the first theoretical investigations of the process that studied the deposition on Newton fluids on flat 
substrates. And, through Equation 9 the thickness is found to be related with the angular speed $(\omega)$ by a factor of $1 / \sqrt{t} 29$.

\section{Methodology}

\subsection{Technical specifications}

The understanding of the mathematical models for the spin coating Equations 1-9 is necessary to control all the variables of the process and build a device with high efficiency on the deposition of films.

The rotation is a parameter that affects the thickness and homogeneity of the film ${ }^{5,24,26-29}$. The engine must provide sufficient torque to rotate the substrate along with the dropped solution for a successful deposition. The device must be free of vibrations to avoid non homogeneous films. The machine, also, must be manufactured at a low cost.

After studying all the variables involved and the 3D modelling of the components, the pieces of the device were fabricated. The first part was the machine structure, made with polystyrene of dimensions 300x400x200 mm and thickness of $4.0 \mathrm{~mm}$. This piece has the function of sustaining the engine, the substrate holder, the electrical board, the power supply and the cables to connect with the outside net (Figure 2).

In the center of the device, it was annexed an engine of continuous current used to lift up and lower the windows of cars, acquired at a local shop (Figure 3). These engines have high torque ${ }^{31}$ and rotations around 5000 per minute (rpm), without gear (Figure 3b). With the gearing system (Figure 3a) the rotation is reduced to avoid accidents. Table 1 has the parameters and values linked to the engine.

When using the engine on the spin coater, the worm gear was taken out and the shaft was turned to remove the thread. After machining the shaft (Figure 3b), the same was linked to the central piece of the device with 2 self-tapping screws ø $3.50 \times 30.00 \mathrm{~mm}$ for fixing.

The engine rotation was controlled by a serial port of communication of the computer, with a built electrical board, that links the user, the computer and the engine. The user informs the desired rotation, which is transmitted by the serial port of the computer through the control board, that sends a signal to the engine, which is read by an infrared sensor (Figure 4). This information is read and interpreted by a PWM (Pulse Width Modulation) command. Besides controlling the communication, the integrated circuit aims to give electrical support to feed the motor coils through a voltage supply as indicated by Figure 5 .

The tension supply to the engine was done through an adaptation of a computer supply source that converted an AC (alternating current) 220 Volts into a CC (continuous current) 12 Volts, corresponding to the engine voltage.

A LED (light emitting diode) was fixated in the device superior part, to guide the user about the information sent to the serial port of the computer. As such, by turning the device $\mathrm{ON}$, the engine sends an electrical pulse to the LED. As it is, by sending the rotation data to the engine serial port, the LED sends an electrical pulse.

A language written in C\#(Sharp) allowed the control of the information sent by the serial port. The system developed

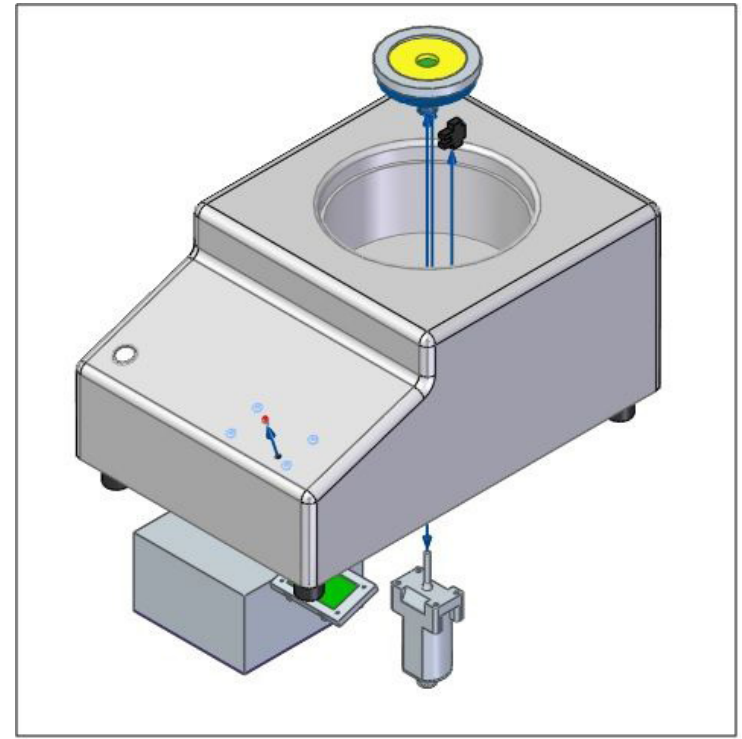

Figure 2. 3D model of spin coater developed.
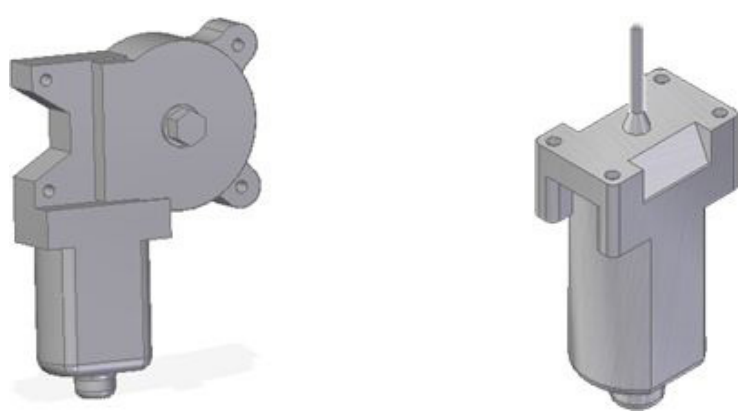

Figure 3. a) 3D model of the engine with the gear system. b) 3D model of the engine after machining

Table 1. Engine data ${ }^{31}$

\begin{tabular}{cc}
\hline Parameters & Value \\
\hline Motor voltage rating & $12.00 \mathrm{~V}$ \\
\hline Max. rated torque & $12.00 \mathrm{~N} . \mathrm{m}$ \\
\hline No load current & $2.80 \mathrm{~A}$ \\
\hline No load speed & $(80-100) \mathrm{rpm}$ \\
\hline Rated current & $8.00 \mathrm{~A}$ \\
\hline
\end{tabular}

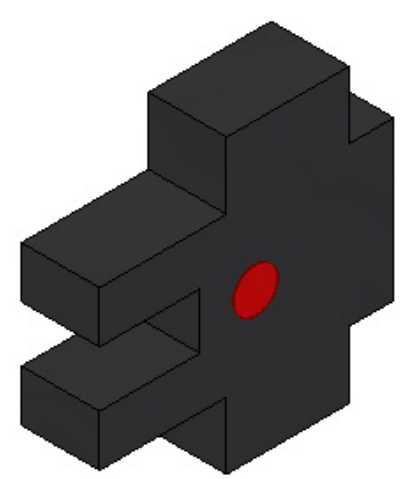

Figure 4. Infrared sensor. 

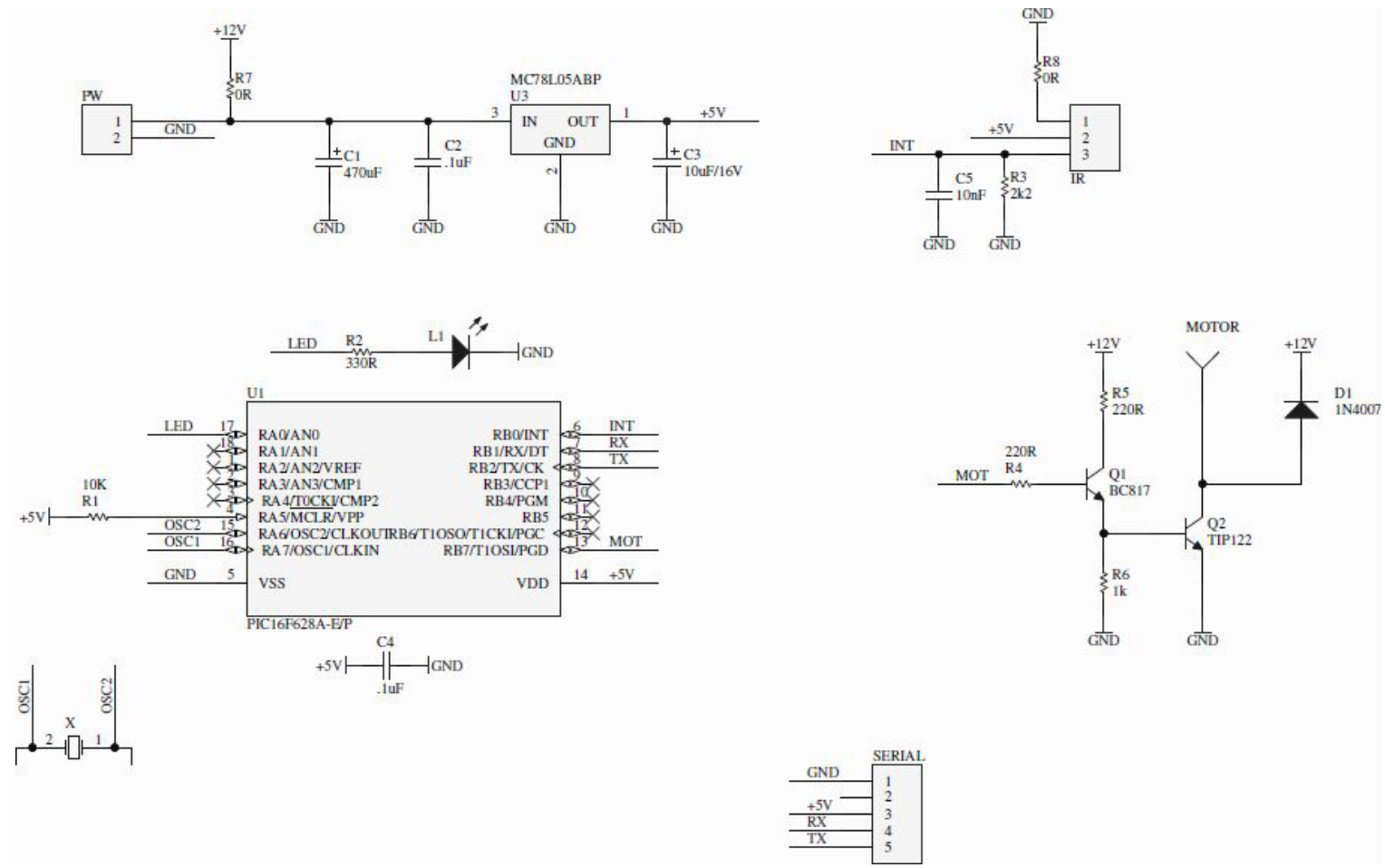

Figure 5. Spin coater wiring diagram.

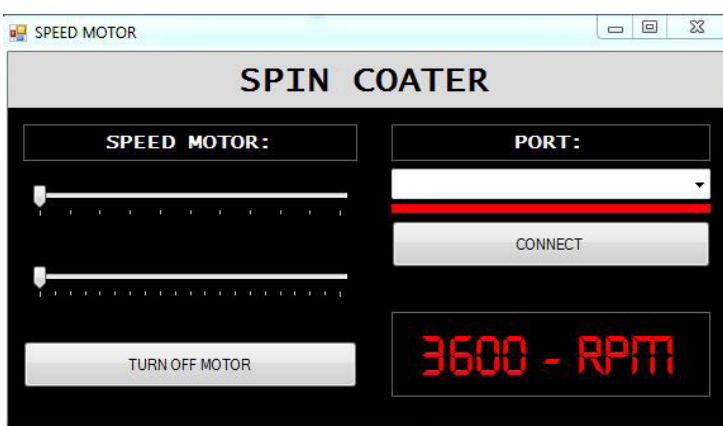

Figure 6. Program interface developed for spin coater.

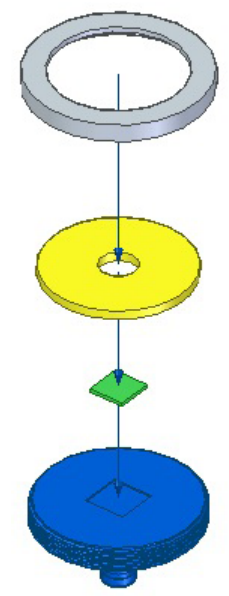

Figure 7. Substrate holder. with loops functions enabled the interaction between the user and the device. It is possible, for example, to change the speed in a single window. Figure 6 represents the program.

Another highlight of this project is the substrate holder (Figure 7), that makes it possible to fixate the substrate on the device without tapes or vacuum pumps. Also, the software eliminated the use of electronic components, reducing the total costs.

Figure 8 represents the spin coater and Table 2 lists the components used to assemble the device, with all specifications.

\section{Procedures}

\subsection{Calibration of the spin coater speed}

The tachometer DT - 2234C S216605 read the speed in rpm. These values were later on compared with the ones obtaines by the C\#(Sharp) software.

\subsection{Materials}

All the chemicals (Aldrich, Vetec and Dynamic) were used without further purification. The commercial glass of FTO (Solaronix) was used as substrate, with average surface resistance between $20-30 \Omega / \mathrm{m}^{2}$ and dimensions of $25.00 \times 25.00 \times 2.00 \mathrm{~mm}$.

\subsection{Preparation and deposition of the $\mathrm{TiO}_{2}$ solution}

The solution dropped was made with $1.50 \mathrm{~g}$ of $\mathrm{TiO}_{2}$ powder (Aldrich 99\%), anatase phase, and $21 \mathrm{~nm}$ average nominal size particle on $3 \mathrm{~mL}$ of glacial acetic acid (Vetec $99.7 \%$ ) and 
$0.50 \mathrm{~mL}$ of Triton X (Vetec $99 \%$ ). The solution was obtained after magnetic agitation for 15 minutes at room temperature.

Before depositing the solutions, the substrates were cleaned in an ultrasonic bath with acetone (Dynamic) (15 minutes), isopropyl alcohol (Dynamic) (99.8\%) (15 minutes) and deionized water (15 minutes).

The $0.08 \mathrm{~mL} \mathrm{TiO}_{2}$ solution was dropped on conductive glass (FTO) at rest, at the beginning, fixated on the substrate

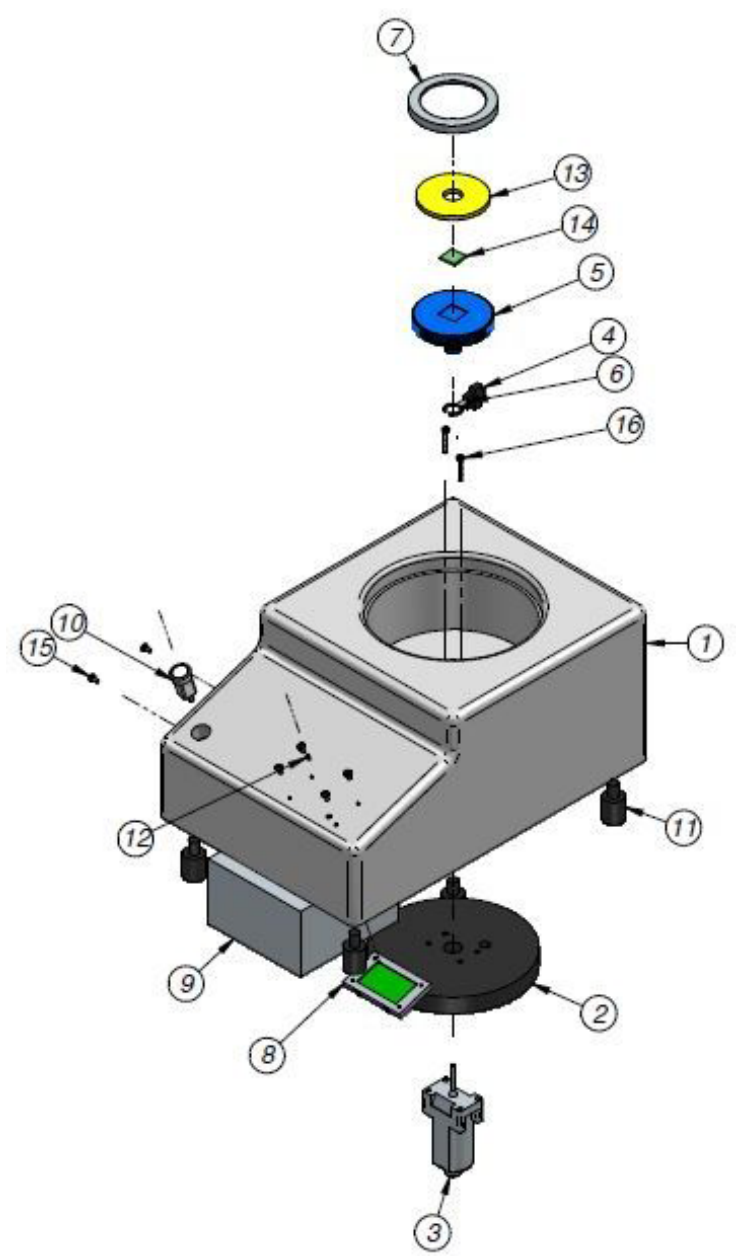

Figure 8. Exploded view.

Table 2. Components list.

\begin{tabular}{ccccc}
\hline Item & Description & Material & Quantity & Manufacturer \\
\hline 1 & External structure & Polystyrene sheet $\# 4,0 \mathrm{~mm}$ & 1 & - \\
\hline 2 & Anti-impact engine & Ethylene vinyl acetate & 1 & - \\
\hline 3 & Engine & - & 1 & Bosh \\
\hline 4 & Infrared sensor & - & 1 & Sense eletrônica Ltda. \\
\hline 5 & Substrate holder & Teflon & 1 & - \\
\hline 6 & Sensor marker & Polypropylene & 1 & - \\
\hline 7 & Substrate cover & Polyamide & 1 & - \\
\hline 8 & PCI & Phenolite & 1 & - \\
\hline 9 & 12 Volts Source & - & 1 & - \\
\hline 10 & Key On-Off & Polypropylene & 1 & - \\
\hline 11 & Bottom support & Ethylene vinyl acetate & 4 & - \\
\hline 12 & Led & - & 1 & - \\
\hline 13 & Substrate regulator & Polyamide & 1 & - \\
\hline 14 & Substrate & FTO & 1 & Solaronix \\
\hline 15 & Self-tapping screw Ø $3,5 \times 15 \mathrm{~mm}$ & Steel sae 1020 & 6 & - \\
\hline 16 & Self-tapping screw Ø $3,5 \times 30 \mathrm{~mm}$ & Steel sae 1020 & 2 & - \\
\hline
\end{tabular}


holder (Figure 7). Initially, the substrate was rotated at $1800 \mathrm{rpm}$ for $30 \mathrm{~seconds}$, and, at the end, at $5000 \mathrm{rpm}$ for 30 seconds to evaporate the solvents still present, monitoring the thickness and homogeneity of the film. After the deposition, the glass was thermally treated on a muffle furnace at $450^{\circ} \mathrm{C}$ for 30 minutes at a heating rate of $10^{\circ} \mathrm{C} /$ minutes.

\subsection{Assemble of the dye sensitized solar cells (DSSCs)}

The DSSCs (Figure 9) were assembled with two different photoanodes (PA). The first one made with the FTO and the commercial $\mathrm{TiO}_{2}$ (Solaronix-reference 74111 ), with a single layer of $\mathrm{TiO}_{2}$ dropped by the screen printing technique on the substrate. The second was made with a layer of $\mathrm{TiO}_{2}$ dropped by spin coating, using the solution prepared in section 4.2, over the commercial layer. Both cells had an active area of $0.25 \mathrm{~cm}^{2}$.

The PA were immersed in an isopropyl alcohol solution with dye N719 (Solaronix) (0.0003 M) for 24 hours.

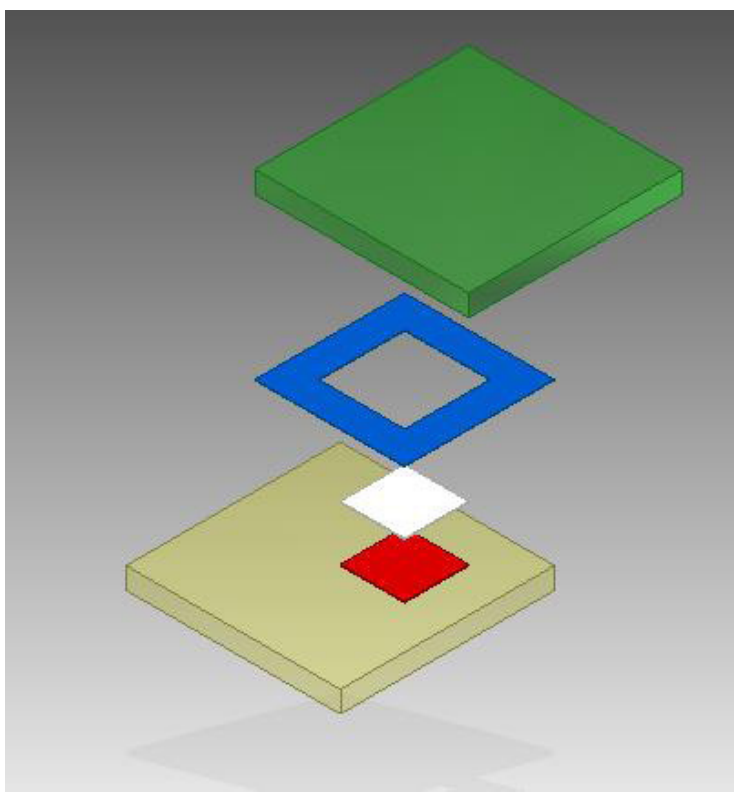

Figure 9. Cell assembled with the $\mathrm{TiO}_{2}$ dropped by spin coating.
Following, the PA were sandwich assembled with a counter electrode (CE) of platinum (Pt) (Solaronix). Each pair of PA and CE had a thermoplastic polymer (Surlyn $\left.{ }^{@} 1702\right)$, heated at $60^{\circ} \mathrm{C}$ for 1 minute, between them. Also, between the PA and the CE, there was an electrolytic solution with the NA-50 (Solaronix) iodide/triiodide. The cells are similar to the Grätzell ${ }^{32-35}$

\section{Results and Discussion}

\subsection{Speed analysis (rpm)}

The initial tests were performed with a tachometer DT - 2234C S216605 with speed sensor to monitor the spin coater speed. Table 3 shows the speed indicated by the software and the ones by the tachometer, and the average measurements. From the data, it was possible to obtain a $95 \%$ precision between measurements from the software and the tachometer.

\subsection{Deposition of the $\mathrm{TiO}_{2}$ film through the spin coater}

The optical absorption spectrum of the $\mathrm{TiO}_{2}$ films deposited on FTO were obtained at room temperature in a Cary 100 UV-Vis (UV-VIS), spectrophotometer, with wavelength between 400-800 nm. Figure 10 shows the absorption coefficient versus the wavelength for the $\mathrm{TiO}$ films deposited on FTO by the spin coater. The increase in absorption is linked to a higher thickness of the film ${ }^{36-39}$. High values of absorption are good for the DSSCs because it increases the transportation of charges through the cell due to low resistance ${ }^{36}$. Also, the higher angular speed reduced the absorption, as a consequence of a lower film thickness, which affects the DSSCs efficiency ${ }^{33-42}$.

\subsection{Morphology and thickness of the $\mathrm{TiO}_{2}$ films}

The morphological characterization of the $\mathrm{TiO}_{2}$ films dropped by the spin coater were analyzed using the scanning electron microscope (SEM) Quanta 450 FEG-FEI and atomic force microscopy (AFM) Digital Instruments Nanoscope Multimode IIIa in the contact mode. The Figures 11 and 12 indicate high porous agglomerates in the films. The AFM analysis on the films dropped with 1000,3000 and 5000 rotations per minute (RPM) indicate that by increasing the angular

Table 3. Rotation per minutes values observed for the spin coater.

\begin{tabular}{ccccc}
\hline \multicolumn{5}{c}{ Speed measurements $(\mathrm{rpm})$} \\
\hline Nominal Value (software) & $1^{\mathrm{a}}$ measurement $(\mathrm{rpm})$ & $2^{\mathrm{a}}$ measurement $(\mathrm{rpm})$ & $3^{\mathrm{a}}$ measurement $(\mathrm{rpm})$ & $($ Mean \pm 3$) \mathrm{rpm}$ \\
\hline 0 & 0 & 0 & 0 & 0 \\
\hline 60 & 63.00 & 64.00 & 62.00 & 33.00 \\
\hline 300 & 302.3 & 305.9 & 304.4 & 905.7 \\
\hline 900 & 907.6 & 905.5 & 903.9 & 2533 \\
\hline 2520 & 2531 & 2535 & 2533 & 3032 \\
\hline 3000 & 3034 & 3032 & 3030 & 3345 \\
\hline 3300 & 3343 & 3347 & 3345 & 4145 \\
\hline 3600 & 3615 & 3620 & 3618 & 4383 \\
\hline 4140 & 4147 & 4143 & 4383 & 4504 \\
\hline 4380 & 4381 & 4385 & 4505 & 5111 \\
\hline 4500 & 4500 & 4503 & 5101 & \\
\hline 5100 & 5115 & 5110 & & \\
\hline
\end{tabular}




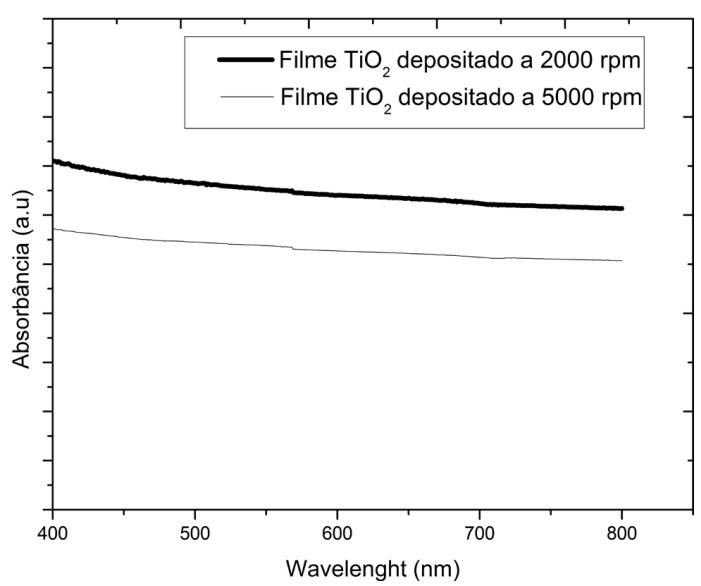

Figure 10. Spectrum of the $\mathrm{TiO}_{2}$ film absorbance deposited at $2000 \mathrm{rpm}$ and $5000 \mathrm{rpm}$ by the spin coater.

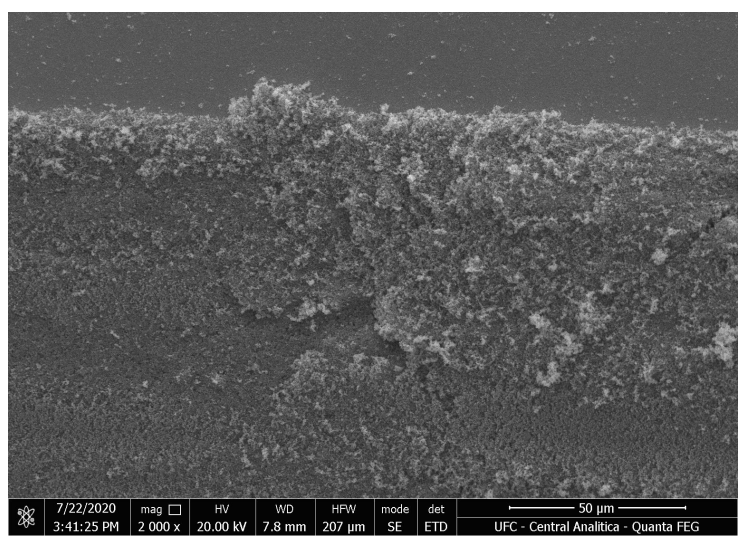

Figure 11. SEM analysis of the $\mathrm{TiO}_{2}$ film

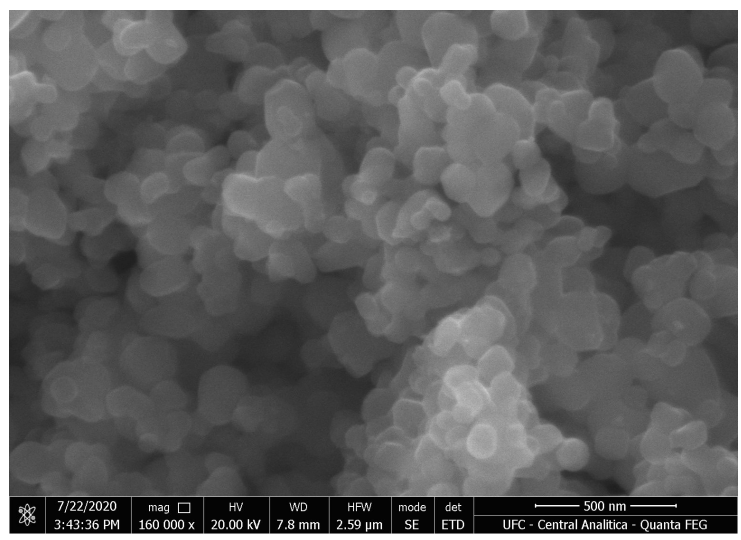

Figure 12. Grain outline of $\mathrm{TiO}_{2}$ dropped by spin coating.

speed, there is a decrease in the average roughness (RMS) (Figures 13a, b and c).

The AFM analysis revealed that, by increasing the speed (1000, 3000 and $5000 \mathrm{rpm})$, the rugosity decreases, $196.212 \mathrm{~nm}$ (Figure 13a), $177.832 \mathrm{~nm}$ (Figure 13b) and $125.576 \mathrm{~nm}$ (Figure 13c), respectively. The grains (Figure 12) presented a spherical shape with aggregates and high porosity, characteristic of the $\mathrm{TiO}_{2}$ particles ${ }^{42-46}$.
The presence of aggregates occurs due to the centrifugal force present in the spin coating process that causes the particles to separate to form a thin layer ${ }^{47}$. The porosity also affects the electrolyte migration ${ }^{42}$. There is a nonlinear relation between the increase in the incident radiation and the produced current, in a cell with low porosity ${ }^{42-45}$. A lower porosity affects the electrolyte mobility ${ }^{43}$. Additionally, low porosities cause more recombination inside the cell, lowering the values of open circuit voltage ${ }^{42,43}$.

Figure 14 shows the image for the thickness of the $\mathrm{TiO}_{2}$ opaque film (Y) obtained at $5000 \mathrm{rpm}$ for $30 \mathrm{~s}$. Table 4 and Figure 15 show that the average thickness of the $\mathrm{TiO}_{2}$ film $\left(\mathrm{Y}_{\mathrm{a}}\right)$ decreases with a higher spin rotation. This behavior is predicted by Equation $9^{24,26-29}$. During the deposition, with Newton fluids, the final thickness relates only with the angular speed $(\omega)$ by a factor of $1 / \sqrt{t} 29$.

Table 4 and Figures 13a, b and c show, as it was predicted, that the average film thickness of the $\mathrm{TiO}_{2}$ film $\left(\mathrm{Y}_{\mathrm{a}}\right)$ decreases with a higher spin coater rotation speed Equation $9^{24,26-29}$.

Analyzing the deposition of the $\mathrm{TiO}_{2}$ solution for different volumes and angular speeds, the final result shows that the thickness does not rely on the volume dispensed (Figure 16). Then, for the deposition using Newton fluids (Equations 1-9), the final thickness depend only on the angular speed $(\omega)$ by a factor of $1 / \sqrt{t}$ (Equation 9) ${ }^{29}$ (Figure 16).

\subsection{Solar cell electrical characterization}

The DSSCs were characterized electrically using potentiostat/galvanostat PGSTAT302N (Metrohm, Switzerland) to obtain the plots current short circuit density (Jsc) versus voltage $(\mathrm{V})$. The J-V measurements were plotted under solar illumination LED of $100 \mathrm{~mW} / \mathrm{cm}^{2}$. The $\mathrm{J}-\mathrm{V}$ characterization is used to determine the DSSC capacity to convert solar light into electrical energy ${ }^{32,33}$.

From the J-V plot (Figures 17 and 18) was possible to calculate the maximum short circuit current (Isc) and the open circuit voltage (Voc). Additionally, the maximum current (Imax), maximum tension (Vmax) and maximum power (Pmax). Using this data, the cell efficiency is found through Equation 10. The results from the J-V plot figures (Figures 17 and 18) can be visualized in Table 5. Cell X1 represents the DSSC assembled with the single layer of $\mathrm{TiO}_{2}$ (commercial Solaronix-74111) and X2 is the double layer of $\mathrm{TiO}_{2}$, the spin coated deposited over the commercial layer.

$\eta=\frac{V_{O C} x J_{S C} x F F}{P_{\text {inc. }}}$

The results for the DSSCs efficiencies (Table 4) showed that the solar cell assembled with the double $\mathrm{TiO}_{2}$ layer (screen print + spin coating) presented efficiency of $\eta=12.74 \%$, which is three times better when compared to the cell with a single layer of $\mathrm{TiO}_{2}$ (screen print), $\eta=4.056$. This increase indicates a higher superficial area for the double layer solar cell, improving the efficiency ${ }^{35-37}$. Similar behavior has been reported ${ }^{42-52}$

It can be evaluated that to achieve a maximum efficiency of the DSSCs, an optimum thickness value must be found. However, this value is not the same for all cells. For example, $\mathrm{TiO}_{2}$ films were fabricated by spin coating with an optimum thickness value of $12 \mu \mathrm{m}$, and DSSCs efficiency of $2.85 \%{ }^{49}$. 

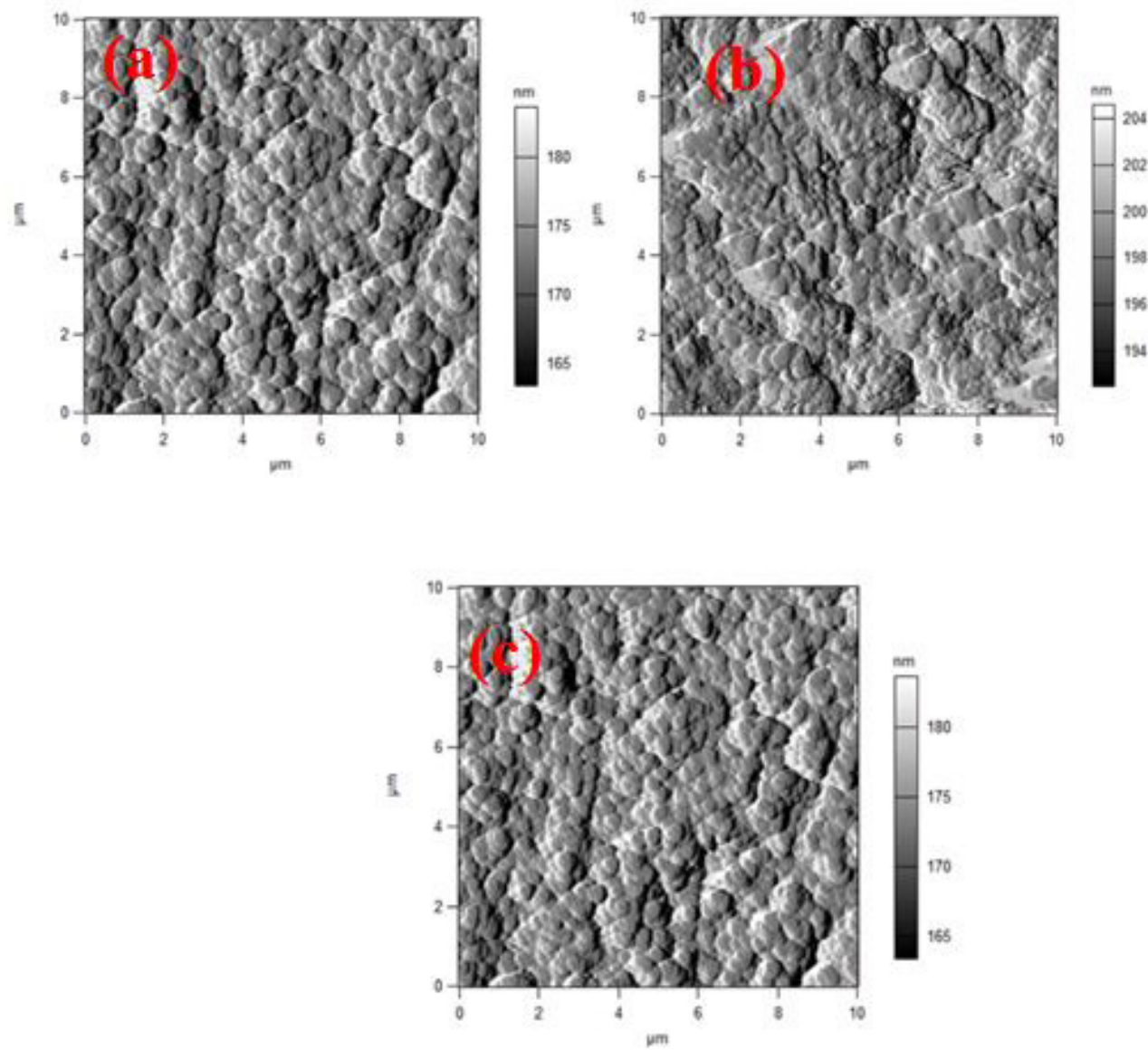

Figure 13. AFM film image of the $\mathrm{TiO}_{2}$ : a) $1000 \mathrm{rpm}$, b) $3000 \mathrm{rpm}$ and c) $5000 \mathrm{rpm}$.

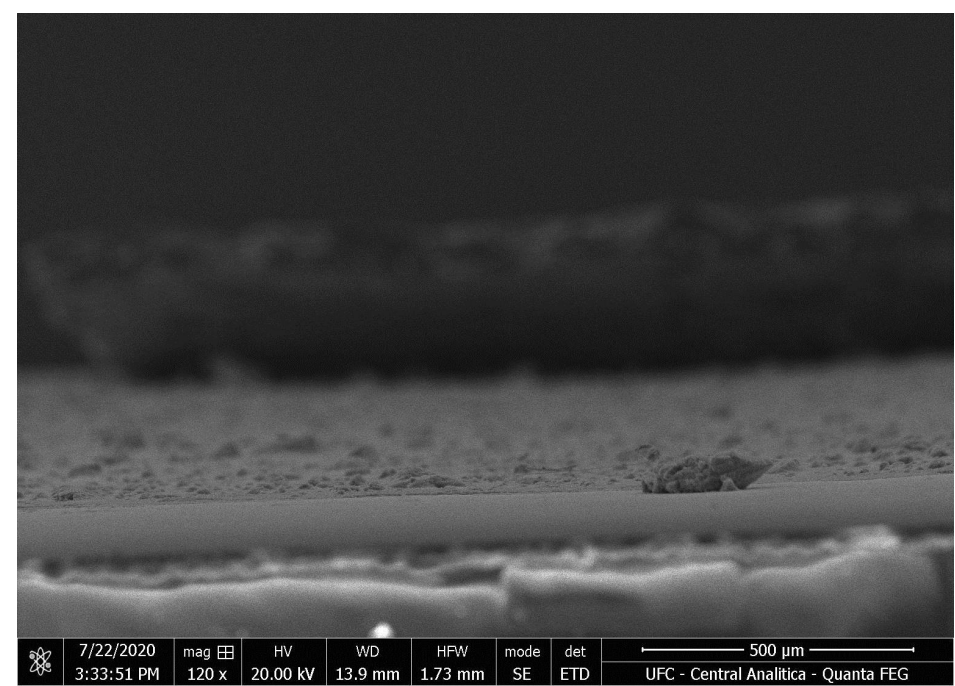

Figure 14. Transversal section of the $\mathrm{TiO}_{2}$ film.

Table 4. Parameters of speed versus thickness.

\begin{tabular}{|c|c|c|c|c|c|c|}
\hline \multicolumn{5}{|c|}{$\mathrm{TiO}_{2}$ Samples } & \multirow{2}{*}{ Average Thickness $(\mathrm{Ya}-\mu \mathrm{m})$} & \multirow{2}{*}{ Speed $\left(\mathrm{RPM} \times 10^{3}\right)$} \\
\hline $\mathrm{Y} 1(\mu \mathrm{m})$ & $\mathrm{Y} 2(\mu \mathrm{m})$ & $\mathrm{Y} 3(\mu \mathrm{m})$ & $\mathrm{Y} 4(\mu \mathrm{m})$ & $\mathrm{Y} 5(\mu \mathrm{m})$ & & \\
\hline 105.2 & 106.7 & 104.9 & 110.0 & 106.6 & 106.7 & 1 \\
\hline 92.29 & 89.96 & 90.38 & 88.40 & 89.93 & 90.19 & 3 \\
\hline 71.06 & 64.60 & 62.45 & 62.45 & 68.94 & 65.90 & 5 \\
\hline
\end{tabular}




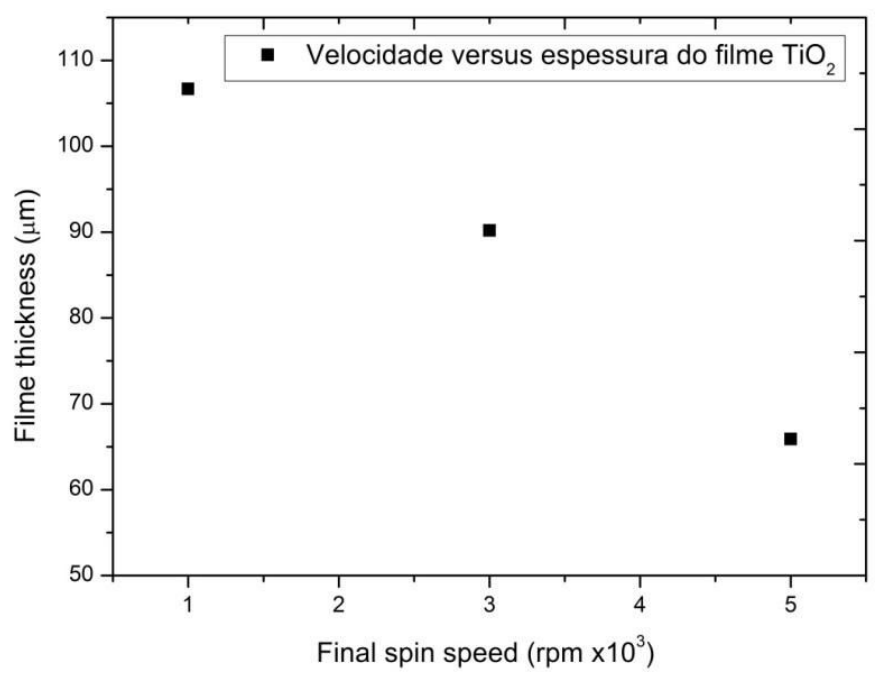

Figure 15. Plot speed versus thickness.

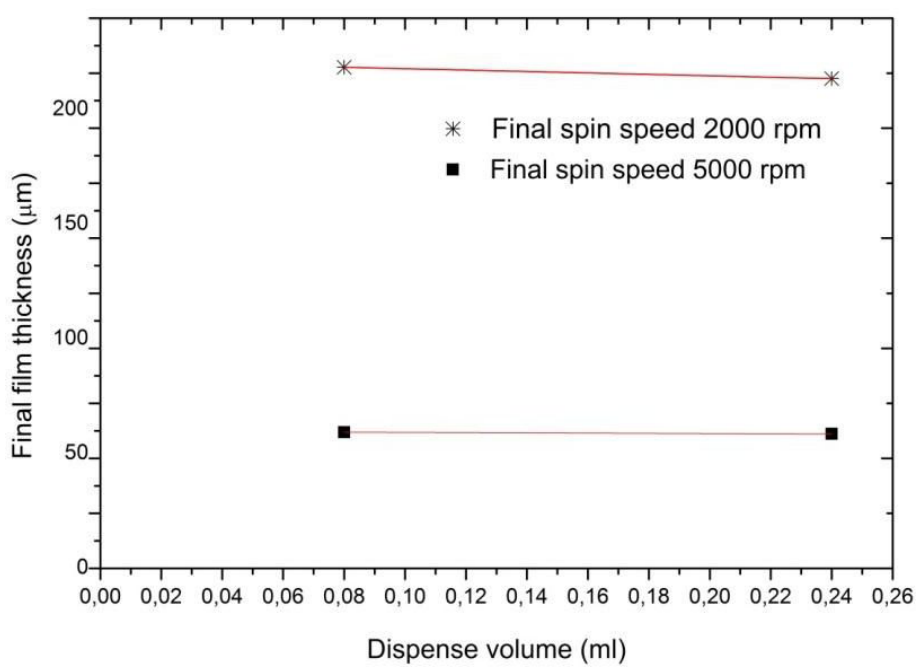

Figure 16. Plot dispensed volume versus thickness.

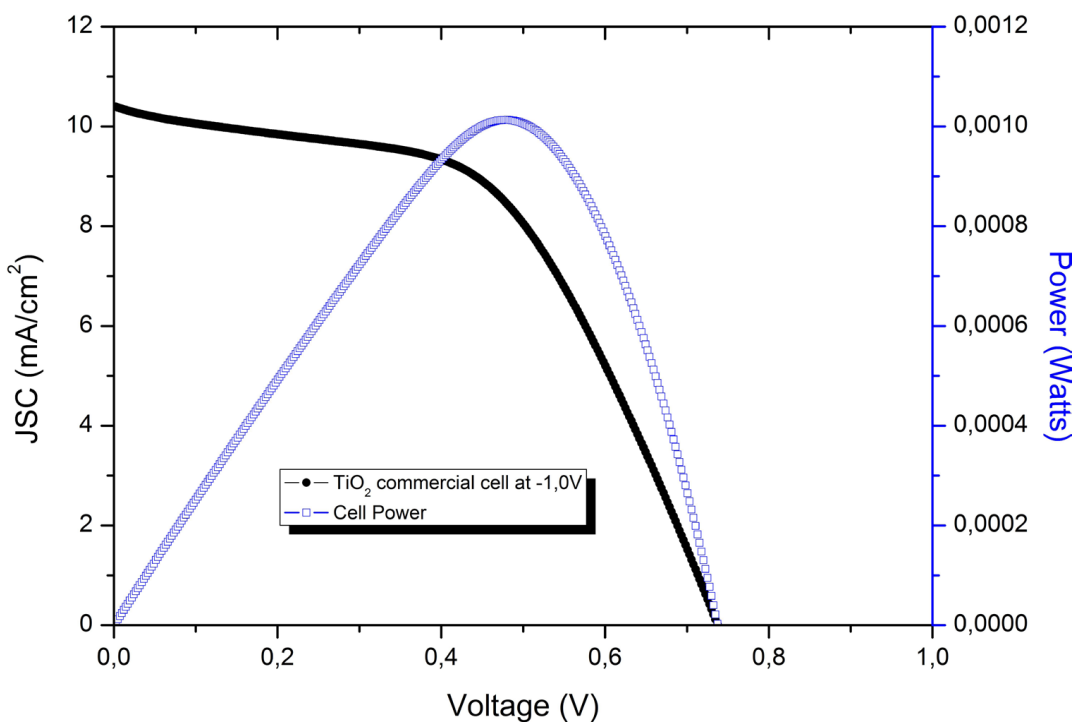

Figure 17. Plot $\mathrm{J}_{\mathrm{SC}}-\mathrm{V}$ of the commercialTiO film. 


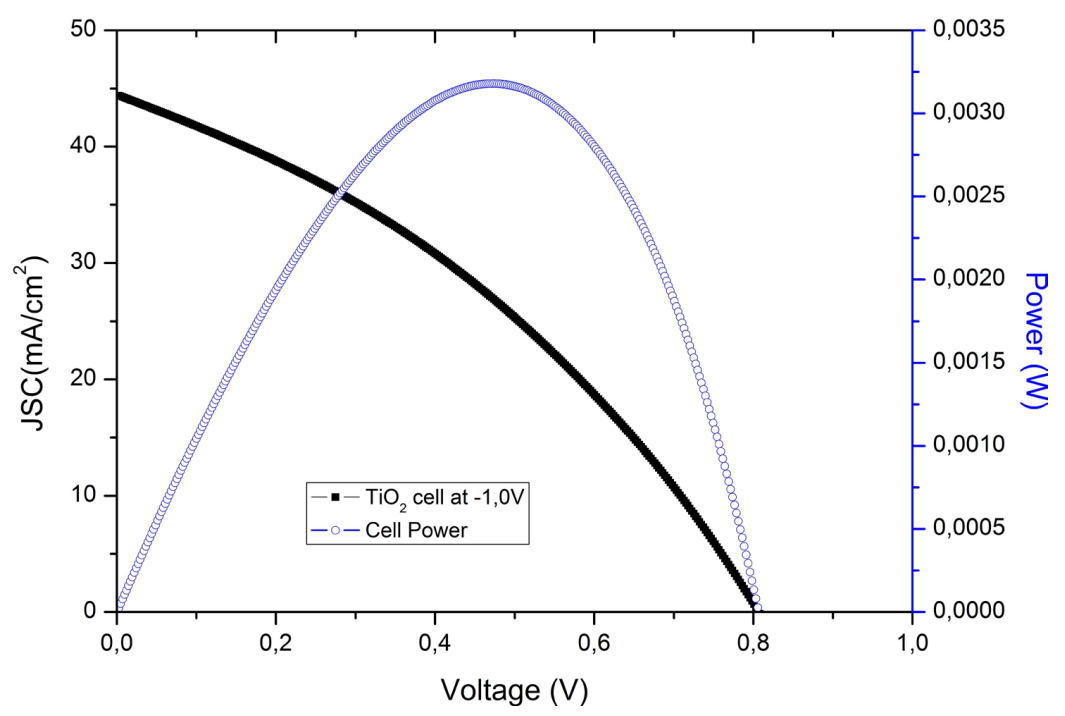

Figure 18. Plot $\mathrm{J}_{\mathrm{SC}}-\mathrm{V}$ of the $\mathrm{TiO}_{2}$ film through the spin coater.

Table 5. Electrical parameters of the solar cell with the commercial $\mathrm{TiO}_{2}$ film (Solaronix - 74111) and the film deposited by the spin coater.

\begin{tabular}{cccccccc}
\hline Sample & $\mathrm{J}_{\mathrm{SC}}\left(\mathrm{mA} / \mathrm{cm}^{2}\right)$ & $\mathrm{V}_{\mathrm{OC}}(\mathrm{V})$ & $\mathrm{FF}$ & $\mathrm{I}_{\mathrm{SC}}(\mathrm{mA})$ & $\mathrm{V}_{\max }(\mathrm{V})$ & Maximum Power $(\mathrm{W})$ & $\eta(\%)$ \\
\hline $\mathrm{X} 1$ & 10.39 & 0.7373 & 0.5292 & 10.39 & 0.4736 & $1.012 \times 10^{-3}$ & 4.056 \\
\hline $\mathrm{X} 2$ & 44.39 & 0.8056 & 0.3561 & 44.39 & 0.4736 & $3.180 \times 10^{-3}$ & 12,74 \\
\hline
\end{tabular}

Then, for a $\mathrm{TiO}_{2}$ film deposited by the assembled spin coater, with thickness of $65.90 \mu \mathrm{m}$, the found efficiency was $\eta=12.74 \%$, result close to the ones found in literature of $13 \%{ }^{40}$. Based on the above mentioned results, the spin coater constructed in this work is able to deposit photoanodes which yield good efficiency results when used on DSSCs.

\section{Conclusion}

The device presented a precision of $95 \%$ between the measured values and the nominal values (software), with close values obtained for the rotation measurements.

Additionally, the increase on the angular speed lowers the absorption spectrum and the thickness of the $\mathrm{TiO}_{2}$ thin films deposited by spin coating.

The results of the morphological characterization indicate that the films deposited have microstructure appropriate for the application on DSSCs, when compared with the Grätzel films: high porosity, nanometer grains e homogeneous films.

The double layer $\mathrm{TiO}_{2}$ films deposited with the help of the spin coater had maximum thickness of $107.6 \mu \mathrm{m}$ and minimum of $65.90 \mu \mathrm{m}$, where the increase in speed reduced the film thickness. For the thickness of $65.90 \mu \mathrm{m}$, for the double layer $\mathrm{TiO}_{2}$ film, the DSSC efficiency was $\eta=12.74 \%$. The DSSC assembled with the single $\mathrm{TiO}_{2}$ layer (commercial) presented efficiency of $\eta=4.056 \%$.

With these results, it is possible to conclude that the spin coater did control successfully the thickness of the films of $\mathrm{TiO}_{2}$. This indicates the possibility of obtaining nanocrystalline films using a low cost device that manufactures photoanodes for dye sensitized solar cells.

\section{Acknowledgments}

The authors would like to acknowledge the Brazilian research agency Fundação cearense de apoio ao desenvolvimento científico e tecnológico (FUNCAP) for the financial support, the Laboratório de Filmes Finos e Energias Renováveis LAFFER for the assistance throughout the research.

\section{References}

1. Nunes VF, Souza APS, Lima F, Oliveira G, Freire FN, Almeida AF. Effects of potential deposition on the parameters of $\mathrm{ZnO}$ dye-sensitized solar cells. Mater Res. 2018;21(4):e20170990.

2. Takahashi Y, Okada S, Tahar RBH, Nakano K, Ban T, Ohya Y. Dip-coating of ITO films. J Non-Cryst Solids. 1997;218:129-34.

3. Kim BM, Rho SG, Kang CH. Effects of TiO2 structures in dyesensitized solar cell. J Nanosci Nanotechnol. 2011;11:1515-7.

4. Chen WF, Koshy P, Sorrell CC. Effects of film topology and contamination as a function of thickness on the photo-induced hydrophilicity of transparent $\mathrm{TiO} 2$ thin films deposited on glass substrates by spin coating. J Mater Sci. 51(5):2465-80.

5. Sahu N, Parija B, Panigrahi S. Fundamental understanding and modeling of spin coating process. Indian J Phys. 2009;83(4):493502.

6. Wagh RA, Roy SP, Patil RS. Synthesis and characterisation of $\mathrm{TiO} 2$ thin film prepared by spin coating technique. International Journal of Innovative Research in Science, Engineering and Technology. 2017; 212587478.

7. Kim D, Woo HK, Lee YM, Kim Y, Choi JH, Oh SJ. Controllable doping and passivation of $\mathrm{ZnO}$ thin films by surface chemistry modification to design low-cost and high-performance thin film transistors. Appl Surf Sci. 2020;509:145289.

8. Ren JH, Huang YT, Li KW, Shen J, Zeng WV, Sheng C-M, et al. Preparation of rare-earth thulium doped tin-oxide thin films 
and their applications in thin film transistors. Applied Surface Science. 493;63-9.

9. Choi PG, Shirahata N, Masuda Y. Tin oxide nanosheet thin film with bridge type structure for gas sensing. Thin Solid Films. 2020

10. Jaiswal J, Sanger A, Tiwari P, Chandra R. $\mathrm{MoS}_{2}$ hybrid heterostructure thin film decorated with CdTe quantum dots for room temperature $\mathrm{NO}_{2}$ gas sensor. Sensors and Actuators B: Chemical. 2019;127437.

11. Shinde SK, Yadav HM, Ramesh S, Bathula C, Maile N, Ghodake GS. High-performance symmetric supercapacitor; nanoflowerlike $\mathrm{NiCo}_{2} \mathrm{O}_{4} / \mathrm{NiCo}_{2} \mathrm{O}_{4}$ thin films synthesized by simple and highly stable chemical method. J Mol Liq. 2018;299:112119.

12. Kaliaraj GS, Ramadoss A. Nickel-zinc sulfide nanocomposite thin film as an efficient cathode material for high-performance hybrid supercapacitors. Mater Sci Semicond Process. 2020;105:104709.

13. Kumar P, Woon KL, Wong WS, Saheed MSM. Hybrid film of single-layer graphene and carbon nanotube as transparent conductive electrode for organic light emitting diode. Synth Met. 2019;257:116186.

14. Yu FX, Zhang Y, Xiong ZY, Ma XJ, Chen P, Xiong ZH, et al. Full coverage all-inorganic cesium lead halide perovskite film for highefficiency light-emitting diodes assisted by 1,3,5-tri (m-pyrid-3-ylphenyl) benzene. Org Electron. 2017;50:480-4.

15. Que W, Uddin A, Hu X. Thin film TiO2 electrodes derived by sol-gel process for photovoltaic applications. J Power Sources. 2006;159:353-6.

16. Sadikin SN, Rahman MY, Umar AAA, Salleh MM. Effect of spin-coating cycle on the properties of $\mathrm{TiO} 2$ thin film and performance of DSSC. Int J Electrochem Sci. 2017;12:5529-38.

17. Lee JG, Cheon JH, Yang HS, Lee DK, Yang HS. Enhancement of photovoltaic performance in dye-sensitized solar cells with the spin-coated TiO2 blocking layer. J Nanosci Nanotechnol. 2012;12:6026-30.

18. Babamahdi Z, Mohammadi MR. Nanostructured TiO2 thick films aided by new viscous gels for dye-sensitized solar cell applications. J Sol-Gel Sci Technol. 82:541-50.

19. Lee CS, Lim JY, Chi WS, Kim JH. Facile, nonhydrothermal, mass-producible synthesis of mesoporous $\mathrm{TiO} 2$ spheres for dye-sensitized solar cells. Electrochim Acta. 2015;173:139-47.

20. Biswas C, Ma Z, Zhu X, Kawaharamura T, Wang K. Atmospheric growth of hybrid $\mathrm{ZnO}$ thin films for inverted polymer solar cells. Sol Energy Mater Sol Cells. 2016;157:1048-56.

21. Ahmad MK, Rasheid NA, Zaki WSW, Ahmed AZ, Abdullah S, Rusop M. Fabrication of transparent titanium dioxide thin film at low temperature by sol-gel spin coating method. In: Proceedings of MUCEET2009. Malaysian Technical Universities Conference on Engineering and Technology; 2009 June 20-22; Garden, Kuantan. Proceedings. Malaysian: Malaysian Technical Universities; 2009. p. 39-41.

22. Zhao P, Tang Q, Zhao X, Tong Y, Liu Y. Highly stable and flexible transparent conductive polymer electrode patterns for large-scale organic transistors. Journal of Colloid and Interface Science. 2018;520:58-63.

23. Yin H, Yan C, Hu H, Ho JKW, Zhan X, Li G, et al. Recent progress of all-polymer solar cells - From chemical structure and device physics to photovoltaic performance. Mater Sci Eng Rep. 2020;140:100542.

24. Aguilar RG, López JO. Low cost instrumentation for spincoating deposition of thin films in an undergraduate laboratory. Lat. Am. J. Phys. Educ. 2011;5(2):368-73.

25. Patil KR, Sathaye SD, Khollam YB, Deshpande SB, Pawaskar NR, Mandale AB. Preparation of TiO2 thin films by modified spin-coating method using an aqueous precursor. Mater Lett. 2003;57:1775-80.

26. Bomside DE, Macosko CW, Scriven LE. Spin coating: one dimensional model. J Appl Phys. 1989;66:5185.
27. Tyona MD. A theoritical study on spin coating technique. Adv Mat Res. 2013;2(4):195-208.

28. Uklistyi AE, Tyabin NV, Ryabchuk GV, Lepekhin GI. Spreading of a non-newtonian liquid over the surface of centrifugal atomizers. Chemical and Petroleum Engineering. 1976;12:519-21.

29. Emslie AG, Bonner FT, Peck LG. Flow of a viscous liquid on a rotating disk. J Appl Phys. 1958;29(5):858.

30. Elfanaoui A, Elhamri E, Boulkaddat L, Ihlal A, Bouabid K, Laanab L, et al. Optical and structural properties of $\mathrm{TiO} 2$ thin films prepared by sol-gel spin coating. International Journal of Hydrogen Energy. 2011;36(6):413-33.

31. Kumar R, Kumar A. Design and hardware development of power window control mechanism using microcontroller. In: International Conference on Signal Processing and Communication (ICSC); 2013; Noida. Proceedings. USA: IEEE.

32. Graetzel M, Janssen RAJ, Mitzi DB, Sargent EH. Materials interface engineering for solution-processed photovoltaics. Nature. 2012;488(304):16.

33. Grätzel M. Dye-sensitized solar cells. J Photochem Photobiol Photochem Rev. 2003;4:145-53.

34. Ito S, Nazeeruddin K, Liska P, Comte P, Charvet R, Péchy $\mathrm{P}$, et al. Photovoltaic characterization of dye-sensitized solar cells: effect of device masking on conversion efficiency. Prog Photovolt Res Appl. 2006;14:589-601.

35. Chandiran AK, Yella A, Mayer MT, Gao P, Nazeeruddin MK, Grätzel M. Sub-nanometer conformal $\mathrm{TiO} 2$ blocking layer for high efficiency solid-state perovskite absorber solar cells. Adv Mater. 2014

36. Singh M, Pathak D, Mahajan A, Bedi RK. Sol gel spin coated $\mathrm{TiO} 2$ films for transparent window applications. J Optoelectron Adv Mater. 2012;14(7-8):624-9.

37. Szeifert JM, Fattakhova-Rohlfing D, Rathouský J, Bein T. Multilayered high surface area "brick and mortar" mesoporous titania films as efficient anodes in dye-sensitized solar cells. Chem Mater. 2012;24:659-63.

38. Tyas LK, Suryana R, Nurosyid F, Ilahi NA. Comparison of Titanium Dioxide (TiO2) nanoparticle-nanofiber and nanofibernanoparticle on the application of dye-sensitized solar cell (DSSC). Journal of Physics: Conf. Series. 2017;795:012019.

39. Jeng MJ, Wung YL, Chang LB, Chow L. Particle size effects of TiO2 layers on the solar efficiency of dye-sensitized solar cells. International Journal of Photoenergy. 2013, 1-9.

40. Mathew S, Yella A, Gao P, Humphry-Baker R, Curchod BFE, Ashari-Astani N, et al. Dye-sensitized solar cells with $13 \%$ efficiency achieved through the molecular engineering of porphyrin sensitizers. Nature Chemistry. 6, 242-7.

41. Dobrzański LA, Szindler MM, Szindler M, Lukaszkowicz K, Drygała A, Prokopowicz MPV. Nanocrystalline TiO2 powder prepared by sol-gel method for dye-sensitized solar cells. Arch. Metall. Mater., 2016;61(2):833-6.

42. Huang WY, Hsieh TL. Dyes amount and light scattering influence on the photocurrent enhancement of titanium dioxide hierarchically structured photoanodes for dye-sensitized solar cells. Coatings. 2020;10:13.

43. Pan K, Zhou W, Tian G, Pan Q, Tian C, Xie T, et al. Dyesensitised solar cells based on large-pore mesoporous $\mathrm{TiO} 2$ with controllable pore diameters. Eur J Inorg Chem. 2011;4730-7.

44. Barbe CJ, Arendse F, Comte P, Jirousek M, Lenzmann F, Shklover V, et al. Nanocrystalline titanium oxide electrodes for photovoltaic applications. J Am Ceram Soc. 1997;80(12):315771.

45. Ni M, Leung MKH, Leung DYC, Sumathy K. An analytical study of the porosity effect on dye-sensitized solar cell performance. Sol Energy Mater Sol Cells. 2006;90:1331-44.

46. Jeng MJ, Wung YL, Chang LB, Chow L. Dye-sensitized solar cells with anatase $\mathrm{TiO} 2$ nanorods prepared by hydrothermal method. International Journal of Photoenergy, 2013;2013:280253. 
47. Merazga A, Al-Subai F, Albaradi AM, Badawi A, Jaber AY, Alghamdi AAB. Effects of sol-gel MgO spin-coating on the performance of TiO2-based dye-sensitized solar cells. Mater Sci Semicond Process. 2016;41:114-20.

48. Liang MS, Fong YK, Khaw CC, Liu CC, Chin SP. Studies on the effects of crystallite sizes and scattering layers on the conversion efficiency of dye-sensitized solar cell. Journal of Power and Energy Engineering. 2014;2:18-24.

49. Kumari JMKW, Sanjeevadharshini N, Dissanayake MAKL, Senadeera GKR, Thotawatthage CA. The effect of TiO2 photoanode film thickness on photovoltaic properties of dye-sensitized solar cells. Ceylon Journal of Science. 2016;45(1):33-41.

50. Mohammed AA, Ahmad ASS, Azeez WA. Fabrication of Dye Sensitized Solar Cell Based on Titanium Dioxide (TiO2). Advances in Materials Physics and Chemistry. 2015;5:361-7.

51. Fan X, Demaree DP, John JMS, Tripathi A, Oliver SRJ. Doublelayer porous $\mathrm{TiO} 2$ electrodes for solid-state dye-sensitized solar cells. Appl Phys Lett. 2008;92:193108.

52. Lien SY, Wuua DS, Yehb WC, Liuc JC. Tri-layer antireflection coatings ( $\mathrm{SiO} 2 / \mathrm{SiO} 2-\mathrm{TiO} 2 / \mathrm{TiO} 2)$ for silicon solar cells using a sol-gel technique. Sol Energy Mater Sol Cells. 2006;90:2710-9. 